\title{
Model Pondok Pesantren di Era Milenial
}

\author{
Nilna Azizatus Shofiyyah \\ Universitas Islam Negeri Sunan Gunung Djati Bandung \\ ashofiyyahnilna@gmail.com \\ Haidir Ali \\ Universitas Islam Negeri Sunan Gunung Djati Bandung \\ haidirali2004@gmail.com \\ Nurhayati Sastraatmadja \\ Universitas Islam Negeri Sunan Gunung Djati Bandung \\ nurhayatisastraatmadja@gmail.com,
}

\begin{abstract}
Pesantren is an oldest education system and considered as an Indonesian cultural product. Along with the change of era that experienced by Indonesian society, pesantren education also has development. With that background, compiler interested to distinguish various models of pesantren in this millennial era. The research method used study literature with a qualitative approach. From this research, can be concluded that the current globalization in the millennial era made its generation not far from the use of technology, the internet, social media and others. This encourages Islamic boarding schools to modernize by looking at the needs of "markets" that require competent human resources. There were many models of millennial Islamic boarding schools. Various developments are carried out, one of them is mastering language, entrepreneurship, ICT (Information and Communication Technology), and other current competencies. This modernization, not only have a positive impact but also problems like pesantren is harder to be able to fulfill its main function, which is to produce tafaquh fiddin people.
\end{abstract}

Keywords: Millennial era, model, boarding school.

Abstrak: Pesantren merupakan sistem pendidikan yang tertua dan dianggap sebagai produk budaya Indonesia. Seiring dengan perubahan zaman yang dialami masyarakat Indonesia, maka pendidikan pada pondok pesantren pun mengalami perkembangan. Dengan latar belakang itulah penyusun tertarik untuk membahas berbagai model pesantren yang muncul pada era millennial ini. Metode penelitian yang digunakan adalah 
kajian pustaka dengan pendekatan kualitatif. Dari penelitian ini dapat disimpulkan bahwa arus globalisasi di era millennial ini telah membuat generasinya tidak dapat jauh dari penggunaan teknologi, internet, media sosial dan lain sebagainya. Hal itu mendorong pondok pesantren untuk melakukan modernisasi dengan cara melihat kebutuhan "pasar" yang membutuhkan sumber daya manusia yang mampu bersaing. Sehingga muncul-lah model-model pondok pesantren era millennial. Berbagai pengembangan dilakukan, diantaranya penguasaan bahasa asing, entrepreneurship, ICT (Information and Communication Technology), serta kompetensi-kompetensi kekinian lainnya. Modernisasi ini, selain berdampak positif juga memicu permasalahan, diantaranya ialah pondok pesantren menjadi semakin sulit untuk memenuhi fungsi pokoknya yaitu menghasilkan manusia-manusia tafaquh fiddin.

Kata Kunci: Era milenial, model, pondok pesantren

\section{Pendahuluan}

Pendidikan saat ini seharusnya menjadi cerminan untuk pendidikan masa yang akan datang. Karena sejatinya pendidikan itu dapat dan harus dilakukan kapanpun dan dimanapun selama manusia itu masih bernyawa. Hal ini membuat pendidikan harus senantiasa mengikuti perkembangan zaman dari generasi ke generasi berikutnya. Sehingga pendidikan akan menjadi jawaban akan kebutuhan dari segala tantangan zaman.

Secara garis besar, pendidikan dapat dibedakan menjadi tiga jenis. Selain pendidikan formal di sekolah, kita juga mengenal pendidikan in-formal dan pendidikan non-formal. Pendidikan non-formal merupakan pendidikan dimana peraturan-peraturan yang ketat dan pasti tidak terlalu diikuti tapi tetap teratur dan dilakukan dengan sadar. Dengan adanya batasan pengertian di atas rupanya pendidikan non-formal tersebut berada antara pendidikan in-formal dan pendidikan formal.

Di Indonesia, ada banyak lembaga-lembaga pendidikan non-formal yang didirikan, namun lembaga pendidikan non-formal yang hingga saat ini masih menjadi pilihan utama dalam pembinaan kepribadian yang sesuai dengan ajaran Agama Islam ialah pondok pesantren. Namun dalam perkembangannya, banyak pondok pesantren yang juga mengadakan pendidikan secara formal di samping non-formal. Hal ini memungkinkan karena telah diatur dalam PP nomor 55 tahun 2007 pasal 14 yang menyatakan bahwa pesantren dapat menyelenggarakan 
satu atau berbagai satuan program pendidikan pada jalur formal, non-formal, dan in-formal.

Pesantren merupakan sistem pendidikan yang tertua saat ini dan dianggap sebagai produk budaya Indonesia yang indigenous. Mulai muncul masyarakat Islam di Nusantara pada abad ke-13, seiring dengan itu mulailah ada pendidikan Agama Islam seperti pesantren. Setelah beberapa abad berlalu, pendidikan tersebut semakin teratur bersamaan dengan tumbuhnya pengajian di berbagai tempat. Bentuk ini kemudian berkembang dengan pendirian tempattempat menginap para pelajar (santri), yang kemudian disebut pesantren.

Pondok pesantren secara umum terbagi menjadi dua jenis, yakni pondok pesantren salafi (tradisional) dan pondok pesantren modern. Kedua jenis ini memiliki persamaan dan perbedaan. Perbedaan ini menjadi karakteristik tersendiri bagi jenis salafi atau modern. Namun kemudian zaman semakin maju, perkembangan teknologi semakin pesat, generasi pun berganti yang kini dikenal dengan generasi milenial dengan karakteristik utamanya adalah ketergantungan generasi ini akan gawai (gadget). Maka menjadi menarik untuk diteliti tentang bagaimana model-model pondok pesantren pada era milenial saat ini.

\section{Sejarah Pondok Pesantren}

Pesantren merupakan suatu sistem pendidikan unik sekaligus khas yang ada di Indonesia dimana mayoritas penduduknya beragama Islam. Dikatakan khas karena pendidikan model pesantren hanya berkembang pesat di Indonesia dan pendidikan seperti ini tidaklah mudah didapatkan di Negara lain. Sedangkan yang dimaksud unik, karena pesantren memiliki karakteristik khusus yang tidak dimiliki secara lengkap oleh sekolah-sekolah umum, seperti kiai, santri, pondok, kitab kuning, dan masjid. Pesantren ini juga pendidikan Islam asli produk Indonesia, di samping memiliki keunikan dan kekhasan. Bapak Pendidikan Islam di Indonesia, demikian bahkan ada yang memberi julukan bagi pesantren seperti itu. $^{1}$

Pesantren memiliki arti tempat untuk tinggal dan belajar santri, karena ia berasal dari kata santri yang diberi tambahan awal pe- dan akhiran -an. Sedangkan kata santri menurut Kamus Bahasa Indonesia berarti orang yang mendalami agama Islam. ${ }^{2}$ Pesantren diartikan lebih gamblang lagi oleh Sudjoko

1 Adnan Mahdi, "Sejarah Dan Peran Pesantren Dalam Pendidikan Di Indonesia," Jurnal Islamic Review 2, no. 1 (2013), hlm. 1-20.

${ }^{2}$ Depdikbud, Kamus Besar Bahasa Indonesia (Jakarta: Balai Pustaka, 1990), hlm. 783. 
Prasojo dengan definisi bahwa pesatren merupakan lembaga pendidikan Islam Indonesia dalam rangka mendalami dan mengamalkan agama Islam di kehidupan sehari hari. Istilah lainnya pesantren disebut sebagai lembaga tafaqquh fiddin. $^{3}$

Raden Rahmat (Sunan Ampel), dianggap sebagai tokoh seungguhnya yang berhasil mendirikan serta mengembangkan pesantren. Sebelum pindah ke Ampel Denta (Surabaya) beliau mendirikan pesantren di Kembang Kuning. Masyarakat Majapahit kemudian mengenal beliau karena misi keagamaan sekaligus pendidikan beliau sukses. Berikutnya tumbuhlah pesantren-pesantren baru yang oleh putra beliau dan para santri dirikan. ${ }^{4}$

Pemerintah Belanda beranggapan bahwa pendidikan pesantren itu jelek sehingga tidak mungkin dikembangkan menjadi sekolah-sekolah modern. Maka sebagai pilihan kedua, Belanda membuat sekolah-sekolah yang berbeda dengan lembaga pendidikan yang terlebih dulu ada. Sejak pemerintah kolonial mendirikan sekolah yang diperuntukkan bagi sebagian bangsa Indonesia tersebut, telah terjadi persaingan antara lembaga pendidikan pesantren dengan lembaga pendidikan colonial. Bentuk perlawanan politis dan fisik pun bermunculan disamping persaingan di sisi ideologis dan cita-cita pendidikan. Pesantrenlah yang mendukung penuh hampir semua pertempuran fisik melawan Belanda, sebagai contoh adalah perang Diponegoro, perang Paderi, perang Banjar hingga perlawanan-perlawanan rakyat yang bersifat lokal yang tersebar di mana-mana, tokoh-tokoh pesantren atau alumni-alumninya memegang peranan utama. ${ }^{5}$

Dalam sejarahnya tentang peran pesantren, dimana sejak kebangkitan nasional sampai dengan perjuangan mempertahankan kemerdekaan RI, pesantren senatiasa tampil dan mampu berpartisipasi secara aktif, maka wajar bila pemerintah RI mengakui pesantren merupakan sumber sekaligus sebagai dasar pendidikan nasional, yang sebab itulah harus diberi bantuan dan bimbingan. Kementrian agama yang membawahi wewenang serta pengembangan itu. Meskipun demikian, pesantren juga tidak luput dari berbagai kritik, hal ini terutama terjadi di saat-saat prakemerdekaan, dimana kondisi pesantren telah mencapai titik kritis sebagai lembaga pendidikan tradisional yang tertutup dan statis. Islam yang disampaikan yakni Islam yang ritualistic serta

\footnotetext{
${ }^{3}$ Sudjoko Prasojo, Profil Pesantren (Jakarta: LP3ES, 1982), hlm. 6.

${ }^{4}$ Wahjoetomo, Perguruan Tinggi Pesantren Pendidikan Alternatif Masa Depan (Jakarta: Gema Insani Press, 1997), hlm. 71.

${ }^{5}$ Sartono Kartodirdjo, Sejarah Nasional Indonesia (Jakarta: Depdikbud, 1975), hlm. 131.
} 
sufistik, juga mengacu kepada peodalisme.6 Untunglah, beberapa pesantren cepat menangkap hal ini dan segera menyesuaikan diri, membuat diri mereka menjadi modern. Dalam rangka berusaha menjawab tantangan zaman dan mengejar ketertinggalan, utamanya di bidang sosial kemasyarakatan, maka pesantren pun mencoba beradaptasi. Karena sebagaimana kita ketahui pesantren pada dasarnya tumbuh serta berkembang dari, oleh, dan untuk masyarakat,

Seiring dengan perkembangan zaman, berbagai inovasi telah dilakukan untuk pengembangan pesantren, baik oleh masyarakat maupun pemerintah. Para santri diharapkan dapat hidup layak di masyarakat jika pendidikannya telah selesai, Dalam rangka itulah pengetahuan umum dan ketrampilan masuk sebgai bekal tambahan.

Digunakannya sistem klasikal dengan memakai sarana serta peralatan pengajaran madrasah seperti yang ada di sekolah-sekolah, bagi pesantren bukanlah sesuatu yang baru. Maka ada pesantren yang lebih cenderung membina dan mengembangkan madrasah-madrasah atau sekolah umum, baik tingkat dasar, menengah maupun perguruan tinggi. Maka dengan sebab itu, saat ini pesantren memiliki kecenderungan-kecenderungan baru untuk merenovasi sistem yang selama ini ada, diantaranya ialah:

1. Mulai akrab dengan metodologi ilmiah

2. Semakin terbuka pada perkembangan di luar pesantren, atau dengan kata lain orientasi pada pendidikan yang fungsional.

3. Diversifikasi program dan kegiatan makin terbuka dan jelas

4. Dapat berfungsi sebagai pusat pengembangan masyarakat.

\section{Peran dan Fungsi Pondok Pesantren}

Suatu lembaga dapat masuk ke dalam kategori pesantren jika memenuhi unsur-unsur pesantren. Dalam unsur-unsur sistem pendidikan di pondok pesantren dikelompokkan sebagai berikut:

1. Aktor atau pelaku, kiai, ustadz, santri, dan pengurus.

2. Sarana perangkat keras: masjid, rumah kiai, asrama ustadz, pondok atau asrama santri, gedung sekolah, atau madrasah, tanah untuk olah raga, pertanian atau peternakan, makam, dan lainnya.

${ }^{6}$ Fuad Anshori, Masa Depan Umat Islam Indonesia (Bandung: al-Bayan, 1993), hlm. 111.

${ }^{7}$ Zuhaerini, Sejarah Pendidikan Islam (Jakarta: Proyek Pembinaan Prasarana dan sarana Perguruan Tinggi Agama, 1986), hlm. 69. 
3. Saran perangkat lunak: tujuan kurikulum, kitab, penilaian, tata tertib, perpustakaan, pusat dokumentasi, penerangan, cara pengajaran (sorogan, bandongan dan halaqah), keterampilan, pusat pengembangan masyarakat, dan alat-alat pendidikan lainnya. ${ }^{8}$

Selain mengkaji ilmu-ilmu agama, di pondok pesantren santri diajarkan pula untuk bertanggung jawab akan ilmu yang telah didapatkan dengan cara mengamalkan-nya. Pondok pesantren juga mengedepankan nilai-nilai kesederhanaan, keikhlasan, serta kemandirian. Kesederhanaan menunjukkan pengunduran diri dari ikatan-ikatan dan hirarki-hirarki masyarakat setempat, dan pencarian suatu makna kehidupan yang lebih dalam yang terkandung dalam hubungan-hubungan sosial. Adapun dari konsep keikhlasan atau pengabdian tanpa memperhitungkan untung rugi pribadi itu terjelmalah makna hubungan baik yang bukan hanya antar santri sendiri, tapi juga antara para santri dengan kiai serta dengan masyarakat. Sedangkan kemandirian ialah menujukkan sikap tidak bergantung kepada orang lain, dengan demikian para santri dituntut untuk menguasai kompetensi sebagai seorang santri serta bagaimana menggunakannya dalam kehidupan bermasyarakat. ${ }^{9}$

Pondok pesantren memiliki andil yang cukup besar khususnya dalam bidang pendidikan di Indonesia. Pondok pesantren yang tersebar di seluruh pelosok negeri ini telah memberikan kontribusi yang begitu besar dalam pembentukan kepribadian masyarakat muslim Indonesia. Hingga kini pondok pesantren masih dipercaya sebagai alternatif pemecahan masalah-masalah pendidikan yang terjadi saat ini. Lembaga tersebut telah banyak melahirkan pemimpin bangsa di masa lalu, kini, dan agaknya juga di masa yang akan datang. Lulusan pondok pesantren tak pelak lagi, banyak yang mengambil partisipasi aktif dalam pembangunan bangsa. ${ }^{10}$

Pesantren adalah basis perjuangan umat Islam dalm mengajarkan agama kepada masyarakat juga sekaligus basis perjuangan untuk merebut kemerdekaan dari tangan penjajah. Pesantren telah menanamkan bibit pendidikan kedapa generasi bangsa yang berbasis di pedesaan. Pesntren mengajarkan kepada santri tentang kemandirian, kewirausahaan, kemajuan ilmu pengetahuan, perbedaan

\footnotetext{
${ }^{8}$ Ahmad Shiddiq, “Tradisi Akademik Pesantren," Jurnal Tadrîs 10, no. 2 (2015), hlm. 218-29.

${ }^{9}$ Ahmad Muhakamurrohman, "Pesantren: Santri, Kiai, Dan Tradisi," Jurnal Kebudayaan Islam IBDA 12, no. 2 (2014), hlm. 109-18.

${ }^{10}$ Nurotun Mumtahanah, "Pengembangan Sistem Pendidikan Pesantren Dalam Meningkatkan Profesionalisme Santri,” AL-HIKMAH Jurnal Studi Keislaman 5, no. 1 (2015), hlm. 54-70.
} 
baik pendapat, suka, ras, agama, dan lain sebagainya. Pesantren telah mengajarkan etika kepada santrinya sebagai dasar pembentukan karakter peserta didik. Dengan demikian, maka pesantren telah memberikan kontribusi yang cukup besar terhadap sistem pendidikan nasional untuk memanusiakan manusia sekaligus memuliakan manusia agar kembali ke kodratnya yang sebenarnya sebagai makhluk ciptaan Allah swt yang paling sempurna dan paling mulia. ${ }^{11}$

Dalam pembentukan sebuah karakter, pondok pesantren memiliki fungsi ganda, yaitu sebagai lembaga pendidikan keagamaan yang berfungsi untuk menyebarluaskan dan mengembangkan ilmu-ilmu keagamaan islam serta sebagai lembaga pengkaderan yang berhasil mencetak kader umat dan kader bangsa. Di dalam pesantren terdapat pengawasan yang ketat menyangkut tata norma atau nilai terutama tentang perilaku peribadatan khusus dan norma-norma muamalah tertentu. Bimbingan dan norma belajar agar menjadi pintar dan cepat selesai dapat dikatakan hampir tidak ada. Maka dapat dikatakan bahwa pendidikan di pesantren tidak terlalu menekankan pada dimensi kognitif, tetapi proses pendidikannya justru lebih menekankan pada dimensi afektif dan psikomotor.

Karakter pesantren yang demikian itu menjadikan pesantren dapat dipandang sebagai institusi yang efektif dalam pembangunan akhlak. Hal inilah yang menjadikan pesantren sebagai jawaban akan permasalahan pendidikan saat ini di tengah perkembangan zaman dan arus globalisasi, karena pendidikan pesantren merupakan pendidikan yang dikenal dengan penekanan pada pendidikan agama sehingga dipercaya mampu untuk mencetak generasi-generasi berkarakter yang sarat dengan nilai-nilai Islami. Dengan demikian pondok pesantren diharapkan mampu mencetak manusia muslim sebagai penyuluh atau pelopor pembangunan yang taqwa, cakap, berbudi luhur untuk bersama-sama bertanggung jawab atas pembangunan dan keselamatan bangsa. ${ }^{12}$

Secara sosiologis, menurut Thomas O'Dea sebagaimana yang dikutip oleh Hamruni, mengungkapkan bahwa setidaknya ada dua peran lembagalembaga keagamaan seperti pesantren, yaitu: peran sebagai directive system dan defensive system. Dalam peran yang pertama (directive system), agama ditempatkan sebagai referensi utama dalam proses perubahan. Dengan demikian, agama akan dapat berfungsi sebagai supremasi moralitas yang memberikan landasan dan kekuatan etik-spiritual masyarakat ketika mereka

${ }^{11}$ Suddin Bani, "Kontribusi Pesantren Dalam Sistem Pendidikan Nasional," AULADUNA 2, no. 2 (2015), hlm. 264-73.

12 M. Ali Mas'udi, "Peran Pesantren Dalam Pembentukan Karakter Bangsa," Jurnal Paradigma 2, no. 1 (2015), hlm. 1-13. 
berdialektika dalam proses perubahan. Dalam peran yang kedua (defensive system), agama menjadi semacam kekuatan kehidupan yang semakin kompleks di tengah derasnya arus perubahan. Masyarakat yang berpegang pada nilai-nilai religius akan mempunyai kemampuan untuk mempertahankan diri dan tidak ada rasa kekhawatiran serta keragu-raguan dalam menghadapi tantangan kehidupan. Dari analisis tersebut bisa dipahami bahwa pesantren tetap menjadi primadona masyarakat dalam membendung derasnya arus globalisasi dan budaya budaya barat yang menggurita. Sehingga prospek pesantren sebagai lembaga pendidikan Islam kedepan masih tetap cerah dan dibutuhkan. Selain itu, pesantren juga menerapkan pengawasan yang ketat menyangkut tata norma, baik peribadatan maupun norma sosial. ${ }^{13}$

Pengembangan pondok pesantren untuk ikut terlibat dalam pembangunan bangsa dan khususnya pembangunan masyarakat sekitarnya adalah akan muncul beberapa wujud kemungkinan, di antaranya adalah:

1. Pesantren sebagai pusat pengembangan potensi dakwah santri untuk masyarakat dan menanta lingkungan sosial tatkala selesai mondok.

2. Pesantren sebagai pusat informasi keislaman, dalam mana masyarakat bisa mendapatkan produk-produk tertentu.

3. Pesantren sebagai tempat forum rembuk tokoh, dalam mana masyarakat bersama kiai dapat berusaha menyelesaikan masalah-masalah social-budaya.

4. Pesantren sebagai Pusat Berbagi Ilmu, dalam mana masyarakat datang ke pesantren untuk mencari ilmu-ilmu agama.

5. Pesantren sebagai tempat wisata keluarga. Pesantren dikembangkan untuk menjadi tempat wisata bagi keluarga yang mana masyarakat akan memperoleh informasi-informasi keagamaan dan pesantren itu sendiri. ${ }^{14}$

\section{Pondok Pesantren dan Generasi Milenial}

Kemajuan zaman juga menyebabkan komposisi penduduk tiap generasi akan berubah, komposisi kelompok baby boomers mulai menurun, jika terkait dengan usia produktif dan komposisi angkatan kerja maka jumlah kelompok generasi $\mathrm{X}$ dan $\mathrm{Y}$ yang terbanyak, bahkan mulai muncul angkatan kerja yang dikenal dengan sebutan generasi Z. Penelitian Bencsik, Csikos, dan Juhez sebagaimana yang dikutip oleh Yanuar Surya Putra, menunjukkan masuknya

${ }^{13}$ Hamruni, "Eksistensi Pesantren Dan Kontribusinya Dalam Pendidikan Karakter," Jurnal Pendidikan Agama Islam XIII, no. 2 (2016), hlm. 197-210.

${ }^{14}$ Hariya Toni, "Pesantren Sebagai Potensi Pengembangan Dakwah Islam," Jurnal Dakwah Dan Komunikasi 1, no. 1 (2016), hlm. 97-110. 
Generasi Z didalam kelompok generasi. Enam kelompok generasi tersebut memiliki karakteristik yang berbeda-beda. Generasi paling muda yakni generasi $Z$ disebut juga i-generation atau generasi internet, karena generasi ini akan sangat bergantung pada internet. Generasi $Z$ hamper sama dengan generasi $Y$, tapi perbedaannya generasi $\mathrm{Z}$ mampu melakukan beberapa kegiatan dalam satu waktu (multi-tasking). Generasi ini telah mengenal teknologi sejak kecil serta terbiasa dengan penggunaan gawai canggih sehingga secara tidak langsung mempengaruhi kepribadian mereka. Teknologi tinggi dalam darah mereka, mereka telah tumbuh di lingkungan yang tidak pasti dan kompleks yang menentukan pandangan mereka tentang pekerjaan, belajar dan dunia Hasil survei Forbes Magazine menunjukkan bahwa generasi $\mathrm{Z}$ adalah generasi global pertama.15

Karakteristik nilai-nilai budaya generasi milenial antara lain: menjadikan teknologi sebagai lifestyle, generasi yang ternaungi (sheltered), lahir dari orang tua yang terdidik, multi-talented, multi-language, ekspresif dan eksploratif, selalu yakin, optimistik, percaya diri, menginginkan kemudahan, dan segala sesuatunya serba instan, prestasi merupakan sesuatu yang harus dicapai, bekerja dan belajar lebih interaktif melalui kerjasama tim, kolaborasi dan kelompok berpikir, mandiri dan terstruktur dalam penggunaan teknologi, communication gadget, dalam akses internet lebih menyukai petunjuk visual/gambar, generasi milenial dalam berkomunikasi bersifat instant communication, real time, network development, lebih terbuka terhadap berbagai akses informasi, tidak peduli akan privasi, membuat status tentang kehidupan sehari-hari mereka telah menjadi budaya, cyberculture yakni sebuah kebudayaan baru di mana seluruh aktivitas kebudayaannya dilakukan dalam dunia maya yang tanpa batas, namun generasi milennial tetap berpandangan bahwa keluarga merupakan pilar yang sangat penting bagi kehidupannya. ${ }^{16}$

Teknologi informasi adalah sarana yang berdasarkan tujuannya diciptakan untuk menciptakan kemaslahatan agama, akal, jiwa, harta dan generasi di masa yang akan datang. Visi baru ini, dapat menginspirasi secara kuat terhadap keberadaan pesantren di Indonesia dalam mencetak generasi yang cerdas dan responsif terhadap kemajuan ilmu dan peradaban dunia. Pesantren

${ }^{15}$ Yanuar Surya Putra, "Theoritical Review: Teori Perbedaan Generasi," Among Makarti 9, no. 18 (2016), hlm. 123-34.

${ }^{16}$ Heru Dwi Wahana, "Pengarub Nilai-Nilai Budaya Generasi Millennial Dan Budaya Sekolab Terbadap Ketahanan Individu (Studi Di SMA Negeri 39, Cijantung, Jakarta)," Jurnal Ketahanan Nasional XXI, no. 1 (2015): 14-22. 
adalah lembaga pendidikan yang sangat kompleks baik dalam konteks ilmu pengetahuan, sosial, budaya, bangsa dan alam semesta. ${ }^{17}$

Pesantren telah menorehkan sumbangsih yang besar dalam proses mencerdaskan generasi bangsa. Namun, dalam konteks kekinian pesantren tidak bisa mengelak dari pengaruh modernisasi, terutama perkembangan zaman yang diiringi oleh kemajuan ilmu pengetahuan dan teknologi. Pesantren dihadapkan pada tantangan-tantangan yang ditimbulkan oleh kehidupan modern. Sedangkan kemampuan pesantren dalam menjawab tantangan tersebut dapat dijadikan parameter seberapa jauh dia dapat mengikuti arus modernisasi. Di tengah-tengah arus modernisasi, pesantren diyakini sebagai lembaga yang dapat menanamkan nilai-nilai islami. Proses internalisasi nilai di pondok pesantren dapat dilakukan melalui langkah-langkah berikut:

1. Tranformasi nilai, yaitu sang kiai membentuk persepsi tentang baik dan buruk.

2. Transaksi nilai, yakni proses komunikasi dua arah antara santri dan kiai.

3. Trans-internalisasi nilai, bahwa proses menyeluruh penanaman nilai Islam adalah adanya kesadaran keberagamaan. ${ }^{18}$

Masalah yang dihapai pesantren terhadap arus modernisasi dapat diklasifikasi-kan sebagai berikut; Pertama, dari segi kepemimpinan pesantren secara kukuh masih terpola dengan kepemimpinan yang sentralistik dan hierarkis yang berpusat pada satu orang Kiai. Kedua, kelemahan di bidang metodologi, pesantren mempunyai tradisi yang kuat di bidang transmisi keilmuan klasik. Tetapi kurangnya metodologi, proses transmisi ini hanya akan menghasilkan penumpukan keilmuan. Ketiga, kurikulum pesantren yang kurang relevan. Hal tersebut umunya pesantren sebagai lembaga pendidikan Islam, materi pembelajarannya lebih mengutamakan pelajaran agama Islam yang bersumber dari kitab-kitab klasik, seperti tauhid, hadits, tafsir, fiqih dan sejenisnya. Keempat, terjadinya disorientasi, yakni pesantren kehilangan kemampuan mendefinisikan dan memosisikan dirinya di tengah realitas sosial yang sekarang ini mengalami perubahan yang demikian cepat.

Dari keempat persoalan tersebut Azra menawarkan solusi. Untuk permasalahan pertama dapat diselesaikan dengan pembaruan sistem manajemen

\footnotetext{
${ }^{17}$ Mohammad Arif, "Perkembangan Pesantren Di Era Teknologi," Jurnal Media Pendidikan 28, no. 2 (2013): 307-22.

${ }_{18}$ Andewi Suhartini, “The Internalization of Islamic V alues in Pesantren," Jurnal Pendidikan Islam 2, no. 3 (2016): 429-44.
} 
dan kepemimpinan. Kepemimpinan yang semula besifat sentralistik dan hierarkis yang berpusat pada satu orang Kiai, harus ditransformasikan menjadi manajemen dan kepemimpinan kolektif. Masalah kedua dapat diatasi dengan kontekstualisasi dan improvisasi metode pembelajaran atau bahkan membangun sebuah paradigma baru yang berorientasi pada paradigma emansipatoris. Masalah ketiga dapat diatasi dengan cara tidak jauh berbeda dengan masalah kedua, yakni kontekstualisasi kurikulum dengan zaman yang tengah berlangsung. Adapun masalah keempat dapat diatasi dengan mengimplementasikan kaidah hukum "Al-Mukhafadzatu 'ala al-qadim al-ashalih wa al-akhzu bi al-jadid al-ashlah," artinya melestarikan nilai Islam yang baik dan mengambil nilai-nilai baru yang sesuai dengan konteks zaman. ${ }^{19}$

Dalam upaya menyesuaikan diri dengan modernitas yang terus berkembang, pondok pesantren memiliki dua tanggung jawab secara bersamaan, yaitu sebagai lembaga pendidikan agama Islam dan sebagai bagian integral masyarakat. Sebagai lembaga pendidikan Islam, pesantren sudah selayaknya dan harus menjadi lembaga yang berfokus pada pembentukan santri yang tafaqquh fiddin. Kemudian sebagai bagian intergral masyarakat, pesantren juga bertanggung jawab terhadap perubahan dan rekayasa sosial (social engineering). ${ }^{20}$

Di sisi lain, beberapa pesantren masih mempertahankan gaya tradisional, atau yang dikenal dengan istilah pesantren salaf. Pesantren salaf masih eksis hingga kini karena pertama, peran kiai sebagai penentu kebijakan di pesantren. Kiai merupakan penjaga terhadap eksistensi pesantren salaf. Setiap ide, gagasan, usulan dan keputusan berdasarkan restu kiai. Kedua, keberadaan nilai-nilai keberkahan yang selalu dipertahankan dan nilai hormat dan patuh terhadap kiai. Ketiga, kurikulum pesantren salaf yang dianggap dapat membuat santri menguasai ilmu-ilmu keagamaan secala lebih luas. Keempat, kepercayaan masyarakat terhadap pesantren salaf. Hingga kini masyarakat masih mempercayai dan sangat menghormati tokoh-tokoh pendiri pesantren salaf dan keluarganya. Masyarakat menjadikan tokoh-tokoh tersebut sebagai rujukan utama atas segala permasalahan mereka, terlebih lagi tentang masalah agama.

\footnotetext{
${ }^{19}$ Muhammad Heriyudanta, "Modernisasi Pendidikan Pesantren Perspektif Azyumardi Azra, Mudarrisa," Jurnal Kajian Pendidikan Islam 8, no. 1 (2016), hlm. 145-72.

${ }^{20}$ Wahyu Iryana, “Tantangan Pesantren Salaf Di Era Modern," Jurnal Al-Murabbi 2, no. 1 (2015), hlm. 75-87.
} 
Empath al inilah yang menyebabkan pesantren salaf masih terus bertahan hingga kini. $^{21}$

\section{Model Pondok Pesantren di Era Milenial}

Era milennial adalah era yang ditandai antara lain oleh lahirnya generasi yang memiliki ciri-ciri: 1) suka dengan kebebasan; 2) senang melakukan personalisasi; 3) mengandalkan kecepatan informasi yang instan; 4) suka belajar; 5) bekerja dengan lingkungan inovatif; 6) aktif berkolaborasi, dan 7) hyper technology; 8) critivcal, yakni terbiasa berfikir out of the box, kaya ide dan gagasan; 9) Confidence, yakni mereka sangat percaya diri dan berani mengungkapkan pendapat tanpa ragu-ragu; 10) Connected, yakni merupakan generasi yang pandai bersosialisasi, terutama dalam komunitas yang mereka ikuti; 11) berselancar di media sosial dan internet 12) sebagai akibat dari ketergantungan yang tinggi terhadap internet dan media sosial, mereka menjadi pribadi yang malas, tidak mendalam, tidak membumi, atau tidak bersosialisasi; 13) cenderung lemah dalam nilai-nilai kebersamaan, kegotong-royongan, kehangatan lingkungan dan kepedulian sosial; 14) cenderung bebas, kebaratbaratan dan tidak memperhatikan etik dan aturan formal, adat istiadat, serta tata krama.

Peserta didik di era milenia memiliki sikap ketergantungan terhadap media sosial, sementara mereka belum dapat memilah dan memilih informasi yang di terimanya. Oleh karena itu guru di era milenia perlu mempersiapkan diri dengan memperbaiki sikap dan kompetensinya, sehingga menjadi figur yang menginspirasi peserta didiknya.

Rabmatan lil alamin merupakan ciri keagungan Islam, yang penjabaran secara kongkrit diantaranya; orang lain ikut menikmatinya, merasakan faedahnya, terangkat martabatnya, siapapun membutuhkan-nya dan semua orang terbantu olehnya. Adapun nilai-nilai rahmatan lil alamin yang harus dimiliki guru agar mampu membimbing anak di era milenia, diantaranya, humanis, kerjasama (networking), sosial-profetik, toleransi dan pluralisme, keseimbangan, keteladanan, dialogis serta peningkatan kualitas sumber daya manusia. ${ }^{22}$ Baik secara normatif, filosofis dan historis, pendidikan Islam siap menghadapi era milennial. Yakni siap menyiapkan sumber daya manusia yang dibutuhkan di era

${ }^{21}$ Rustam Ibrahim, "Eksistensi Pesantren Salaf Di Tengah Arus Pendidikan Modern (Studi Multisitus Pada Beberapa Pesantren Salaf Di Jawa Tengah)," Jurnal Analisa 21, no. 02 (2014): 253-63.

${ }^{22}$ Miftah Mucharomah, "Guru Di Era Milenia Dalam Bingkai Rabmatan Lil Alamin," Edukasia Islamika 2, no. 2 (2017): 201-21. 
millenial, dan sekaligus dapat mengatasi berbagai problema kehidupan yang timbul di era tersebut. ${ }^{23}$

Setidaknya ada tiga aspek dalam modernisasi, inovasi, dan pembaruan pesantren, yaitu metode, isi materi, dan manajemen. ${ }^{24}$ Sehingga seiring dengan perkembangan zaman, maka terdapat beberapa hal yang mengalamai pembaharuan atau perubahan dalam pesantren, yakni:

1. Pembaharuan di Bidang Furu'

Hal-hal yang bersifat furu' (cabang) telah mengalami perubahan guna menyesuaikan dengan kebutuhan masyarakat secara lebih luas. Perubahan ini bukanlah menganti keseluruhan sistem pesantren, tetapi pembaruan terjadi pada hal-hal yang dianggap sebagai pelengkap, bukan hal inti pondok pesantren. Perubahan ini misalnya terjadi pada kurikulum serta kegiatan ekstrakurikuler pesantren. Penggunaan bahasa juga telah mengalami perubahan, yang awalnya menggunakan bahasa daerah, kini telah berubah menggunakan bahasa Indonesia.

2. Kebijakan Pemerintah dan Pendidikan

Pemerintah melalui Departemen Agama telah mengeluarkan kebijaksanaan-nya dalam pendidikan, yaitu dengan SK Menag tentang penyelenggaraan pendidikan agama. Maka berdirilah Madrasah Ibtidaiyah, Madrasa Tsanawiyah, Madrasah Aliyah serta Institut Agama Islam Negeri (IAIN) dengan tujuan mencetak ulama yang dapat menjawab tantangan zaman dan memberi kesempatan kepada warga Indonesia yang mayoritas Muslim untuk mendalami ilmu agama.

3. Pendidikan Islam Alternatif

Dewasa ini mulai berkembang pola pendidikan alternatif. Kekurangankekurangan yang ada pada pondok pesantren mulai dibenahi sehingga kemudian bermunculan sekolah-sekolah yang menganut sistem pesantren tetapi tidak menggunakan nama pesantren, seperti munculnya SMP Plus atau SMA terpadu dan lain sebagainya. Hal ini dilakukan sebagai strategi pemasaran, karena tidak

23 Abuddin Nata, "Pendidikan Islam Di Era Milenial," Jurnal Pendidikan Islam Conciencia XVII, no. 1 (2018), hlm. 10-28.

${ }^{24}$ Muhammad Hasan, "Inovasi Dan Modernisasi Pendidikan Pondok Pesantren," Karsa: Jurnal Sosial dan Budaya Keislaman 23, no. 2 (2015):, hlm. 295-305. 
dapat dipungkiri masyarakat masih menganggap bahwa pesantren itu bersifat kolot dan tertutup dari dunia modern. ${ }^{25}$

Hadirnya sistem pendidikan pada pondok pesantren modern, merupakan keniscayaan dalam sistem pendidikan di Indonesia pada umumnya. Sistem ini dianggap tepat bagi dunia pesantren (masa kini) untuk mempersiapkan anak didiknya menjadi pribadi yang siap menghadapi tuntutan zaman. Sistem pendidikan pondok pesantren modern, sebenarnya merupakan kelanjutan dari sistem pendidikan pondok pesantren salafiyah, dimana kemunculannya bertujuan untuk beradaptasi dengan tuntutan zaman yang ada. Sistem pendidikan pondok pesantren modern, berupaya memadukan sistem tradisional dengan sistem modern. Begitu pula sistem pendidikan pondok pesantren modern, lebih terbuka untuk mempelajari kitab kontemporer disamping kitab klasik. Salah satu ciri khas pondok modern adalah bahasa yang digunakan oleh elemen pondok pesantren sebagai upaya menjawab tantangan zaman yang dilaluinya. Mengenai sistem kepemimpinan, pada pondok pesantren modern tidak hanya bertumpu pada kiai satu-satunya, akan tetapi bergesar dari karismatik ke rasionalostik, dari otoriter paternalistik ke diplomatik partisipatif. Pada pondok pesantren modern disamping menjadi lembaga pendidikan, disana juga menjadi lembaga sosial dimana di pesantren modern, santri disiapkan untuk dapat secara cakap berdakwah di tengah-tengah masyarakat. ${ }^{26}$

Namun di sisi lain, adanya gagasan modernisasi pesantren yaitu dengan memasukkan ilmu-ilmu umum ke dalam kurikulum pesantren telah menimbulkan permasalahan. Kemudian muncul persoalan tentang bagaimana tepatnya secara epistimologi menjelaskan ilmu-ilmu empiris dari kerangka epistimologi Islam. Kurikulum yang berorentasi kekinian terus berlanjut dikhawatirkan pesantren tidak mampu lagi memenuhi fungsi pokoknya yaitu menghasilkan manusia-manusia santri. Oleh karena itu pesantren harus mengkaji ulang secara cermat dan hati-hati berbagai gagasan modernisasi tersebut dan pesantren harus lebih mengorientasikan peningkatan kualitas para santrinya ke arah pengusaan ilmu-ilmu agama.

Meskipun ada kekhawatiran tersendiri dalam pergeseran dari pesantren tradisional menjadi pesantren modern, namun aktualisasi modernisme lembaga pendidikan Islam khususnya pondok pesantren menjadi keniscayaan yang perlu

${ }^{25}$ Herman, “Sejarah Pesantren Di Indonesia," Jurnal Al-Ta'dib 6, no. 2 (2013), hlm. 14558.

${ }^{26}$ Abdul Tolib, “Pendidikan Di Pondok Pesantren Modern,” Jurnal Risaalah 1, no. 1 (2015), hlm. 60-66. 
dipertimbangkan guna menjawab sebuah tantangan global. Kekhawatiran tersebut tentu berhubungan dengan identitas pesantren yang bisa saja akan tergerus dengan nilai-nilai global yang begitu bebas. Namun demikian, nilai modernitas yang dibarengi dengan kesiapan jati diri pesantren akan memperkokoh identitas pensatren di kancah dunia. Tentu hal tersebut harus dibarengi dengan kuatnya identitas pesantren sebagai lembaga pendidikan yang mampu berkembang dalam situasi apapun. ${ }^{27}$

Pada sisi lain, terdapat pula pesantren-pesantren lama yang muncul dengan "wajah baru", "elitis", "modern", dan mempunyai public-trust yang akuntabel. Muncul pula, beberapa pesantren baru yang menampilkan orientasi dan pencitraan baru (image building). Keduanya mempunyai segmen "pasar" masyarakat (stakeholder) yang berbeda, namun jika keduanya bersinergi, maka pada ujungnya akan mampu memberikan kontribusi real dan signifikan pada peningkatan kualitas hidup masyarakat muslim dan bangsa Indonesia. ${ }^{28}$

Pada aspek sosial kemasyarakatan, para generasi net (generasi milenial) mengandalkan media sosial sebagai tempat mendapatkan informasi-informasi yang mereka butuhkan termasuk ilmu-ilmu keagamaan. Hadirnya fasilitas media sosial seperti facebook, instagram, youtube dan lainnya telah telah menjadi pusaran informasi dengan ragam pemikiran dan ideologi termasuk yang bertentangan dengan nilai-nilai kebhinekaan dan kerukunan beragama dan berbangsa di Indoensia. Kondisi ini perlu menjadi perhatian pesantren dalam mengimbangi literatur keislaman yang mengandung bias-bias ideologi konservatif dan radikal dengan memproduksi literatur keislaman yang moderat, humanis dan rahmatan lil 'alamain berbasiskan teknologi. ${ }^{29}$ Dengan demikian, saat ini santri tidak lagi sepenuhnya sebagai anak dari tradisi pesantren tetapi juga menjadi perwakilan dunia modern yang berkembang di luar pesantren dunia. Hal ini ditandai dengan kehidupan generasi milenial telah berimplikasi di luar demarkasi budaya-budaya pesantren. ${ }^{30}$

${ }^{27}$ Bashori, "Modernisasi Lembaga Pendidikan Pesantren," Jurnal Ilmu Sosial Mamangan 6, no. 1 (2017), hlm. 145-72.

28 Abdul Basyit, "Pembaharuan Model Pesantren: Respon Terbadap Modernitas," KORDINAT XVI, no. 2 (2017), hlm. 294-324.

${ }^{29}$ Erfan Gazali, "Pesantren Di Antara Generasi Alfa Dan Tantangan Dunia Pendidikan Era Revolusi Industri 4.0,” OASIS: Jurnal Ilmiah Kajian Islam 2, no. 2 (2018), hlm. 94-109.

30 Ahmad Lahmi, "Millenial Santri in Pesantren Santri, Leisure Time, and Activities in Cyberspace," International Journal of Science and Research (IJSR) 7, no. 4 (2018), hlm. 397-403. 


\section{Penutup}

Arus globalisasi di era milenial saat ini membuat generasi ini memiliki karakteristik khusus yang tidak dapat jauh dari penggunaan teknologi, internet, media sosial dan sebagainya. Hal ini membuat pondok pesantren melakukan modernisasi guna memenuhi kebutuhan masyarakat generasi milenial ini. Modernisasi ini dilakukan dengan cara melihat kebutuhan "pasar" yang membutuhkan sumber daya manusia yang mampu bersaing. Maka dari itu muncul-lah model-model pondok pesantren era milenial. Berbagai pengembangan dilakukan, diantaranya penguasaan bahasa asing, entrepreneurship, ICT (Information and Communication Technology), serta kompetensi kekinian lainnya. Hal ini tentu memberi dampak positif bagi pesantren, namun di sisi lain, adanya gagasan modernisasi pesantren ini juga menimbulkan permasalahan. Muncul kekhawatiran pesantren tidak mampu lagi memenuhi fungsi pokoknya yaitu menghasilkan manusia-manusia tafaquh fiddin. Oleh karena itu pesantren harus mengkaji ulang secara cermat dan hatihati berbagai gagasan modernisasi tersebut dan pesantren harus lebih mengorientasikan peningkatan kualitas para santrinya ke arah pengusaan ilmuilmu agama.

\section{Bibliography}

Abdul Basyit. "Pembaharuan Model Pesantren: Respon Terhadap Modernitas." Kordinat XVI, no. 22017

Abdul Tolib. "Pendidikan Di Pondok Pesantren Modern." Jurnal Risaalah 1, no. 12015

Abuddin Nata. "Pendidikan Islam Di Era Milenial." Jurnal Pendidikan Islam Conciencia XVII, no. 12018

Adnan Mahdi. "Sejarah Dan Peran Pesantren Dalam Pendidikan Di Indonesia." Jurnal Islamic Review 2, no. 12013

Ahmad Lahmi. "Millenial Santri in Pesantren Santri, Leisure Time, and Activities in Cyberspace." International Journal of Science and Research (IJSR) 7, no. 42018

Ahmad Muhakamurrohman. "Pesantren: Santri, Kiai, Dan Tradisi." Jurnal Kebudayaan Islam Ibda 12, no. 22014

Ahmad Shiddiq. “Tradisi Akademik Pesantren.” Jurnal Tadrîs 10, no. 2 , 2015 
Andewi Suhartini. "The Internalization of Islamic Values in Pesantren." Jurnal Pendidikan Islam 2, no. 3 , 2016

Bashori. "Modernisasi Lembaga Pendidikan Pesantren." Jurnal Ilmu Sosial Mamangan 6, no. 1, 2017

Depdikbud. Kamus Besar Bahasa Indonesia. Jakarta: Balai Pustaka, 1990.

Erfan Gazali. "Pesantren Di Antara Generasi Alfa Dan Tantangan Dunia Pendidikan Era Revolusi Industri 4.0.” OASIS: Jurnal Ilmiah Kajian Islam 2, no. 2, 2018

Fuad Anshori. Masa Depan Umat Islam Indonesia. Bandung: al-Bayan, 1993.

Hamruni. "Eksistensi Pesantren Dan Kontribusinya Dalam Pendidikan Karakter.” Jurnal Pendidikan Agama Islam XIII, no. 2 (2016): 197-210.

Hariya Toni. "Pesantren Sebagai Potensi Pengembangan Dakwah Islam.” Jurnal Dakwah Dan Komunikasi 1, no. 1, 2016

Herman. "Sejarah Pesantren Di Indonesia." Jurnal Al-Ta'dib 6, no. 2, 2013.

Heru Dwi Wahana. "Pengaruh Nilai-Nilai Budaya Generasi Millennial Dan Budaya Sekolah Terhadap Ketahanan Individu (Studi Di SMA Negeri 39, Cijantung, Jakarta)." Jurnal Ketahanan Nasional XXI, no. 1, 2015

M. Ali Mas'udi. "Peran Pesantren Dalam Pembentukan Karakter Bangsa." Jurnal Paradigma 2, no. 1, 2015.

Miftah Mucharomah. "Guru Di Era Milenia Dalam Bingkai Rahmatan Lil Alamin.” Edukasia Islamika 2, no. 2, 2017

Mohammad Arif. "Perkembangan Pesantren Di Era Teknologi." Jurnal Media Pendidikan 28, no. 2, 2013.

Muhammad Hasan. "Inovasi Dan Modernisasi Pendidikan Pondok Pesantren." KARSA: Jurnal Sosial Dan Budaya Keislaman 23, no. 2 , 2015.

Muhammad Heriyudanta. "Modernisasi Pendidikan Pesantren Perspektif Azyumardi Azra, Mudarrisa.” Jurnal Kajian Pendidikan Islam 8, no. 1, 2016.

Nurotun Mumtahanah. "Pengembangan Sistem Pendidikan Pesantren Dalam Meningkatkan Profesionalisme Santri." Al-Hikmah Jurnal Studi Keislaman 5, no. 1, 2015. 
Rustam Ibrahim. "Eksistensi Pesantren Salaf Di Tengah Arus Pendidikan Modern (Studi Multisitus Pada Beberapa Pesantren Salaf Di Jawa Tengah)." Jurnal Analisa 21, no. 02, 2014.

Sartono Kartodirdjo. Sejarah Nasional Indonesia. Jakarta: Depdikbud, 1975.

Suddin Bani. "Kontribusi Pesantren Dalam Sistem Pendidikan Nasional." Auladuna 2, no. 2, 2015

Sudjoko Prasojo. Profil Pesantren. Jakarta: LP3ES, 1982.

Wahjoetomo. Perguruan Tinggi Pesantren Pendidikan Alternatif Masa Depan. Jakarta: Gema Insani Press, 1997.

Wahyu Iryana. “Tantangan Pesantren Salaf Di Era Modern.” Jurnal Al-Murabbi 2, no. 1. 2015.

Yanuar Surya Putra. "Theoritical Review: Teori Perbedaan Generasi." Among Makarti 9, no. 18, 2016.

Zuhaerini. Sejarah Pendidikan Islam. Jakarta: Proyek Pembinaan Prasarana dan sarana Perguruan Tinggi Agama, 1986. 